\title{
HUMAN T-CELL LYMPHOTROPIC VIRUS TYPES I AND II INFECTIONS IN A COHORT OF PATIENTS WITH NEUROLOGICAL DISORDERS IN BELÉM, PARÁ, BRAZIL
}

\begin{abstract}
SUMMARY
Serum- and/or- cerebrospinal fluid (CSF) samples obtained from 190 patients suffering from chronic, progressive neurological disease were screened for the presence of human T-cell lymphotropic viruses type I (HTLV-I) and type II (HTLV-II) antibodies over a six-year period (1996 to 2001) in Belém, Pará, Brazil. Patients were of both sexes (male subjects, 52\%) with ages ranging from 2 to 79 years (mean, 35.9). Overall, 15 (7.9\%) subjects - of whom 12 (80\%) were female adults - reacted HTLV-I/II-seropositive when screened by enzyme-linked immunosorbent assay (ELISA). Serum samples from 14 of these patients were also analyzed using a recombinant Western blot (WB) assay that yielded HTLV-I-, HTLV-II-, and HTLV-I/II- reactivities for 10 (71.4\%), 3 (21.4\%) and 1 (7.2\%) of them, respectively. The yearly rates of HTLV-I/II antibodies ranged from $2.6 \%$ (2001) to 21.7\% (2000), with progressively increasing seropositivities from 1998 to 2000. Altogether, walking difficulty $(n=5$ subjects), spasticity $(n=4)$ and leg weakness $(n$ =3) accounted for $80 \%$ of symptoms recorded among the 15 patients whose sera had antibodies to HTLV-I/II as detected by ELISA. These findings provide evidence that both HTLV-I and HTLV-II play a role in the development of chronic myelopathy in Belém, Pará, Northern Brazil.
\end{abstract}

KEYWORDS: HTLV-I; HTLV-II; Neurological disease.

\section{INTRODUCTION}

Although primarily recognized as playing a role in the etiology of adult T-cell leukemia (ATL) ${ }^{28}$, the human T cell lymphotropic virus type I (HTLV-I) is currently known to be associated with a variety of clinical conditions in humans. In fact, the broad spectrum of disease manifestations associated with HTLV-I infection also includes HTLV-I associated myelopathy/tropical spastic paraparesis (HAM/TSP) ${ }^{10,27}$, uveitis ${ }^{22}$, chronic inflammatory arthropathy ${ }^{24}$, polymyositis ${ }^{23}$, Sjögren's syndrome ${ }^{20}$, infective dermatitis of children ${ }^{17}$, and facial nerve palsy ${ }^{4}$. Human $\mathrm{T}$ cell lymphotropic virus type II (HTLV-II), in its turn, appears not having absolute association with any human disease to date, even though evidence is currently growing in that it might be etiologically linked to chronic, progressively neurological syndromes, including HAM/TSP ${ }^{6,11}$.

Worldwide, the association between HTLV-I and HAM/TSP has been demonstrated in southwestern Japan, the West Indies, the Seychelle Islands, Africa, and South America ${ }^{11,19}$. Transmission of HTLV-I may occur via sexual contact, breast milk and transfusion of blood products; this latter mode of HTLV transmission has been associated with an increased risk for developing $\mathrm{HAM} / \mathrm{TSP}^{16,26}$.

During the past few years a number of studies in Brazil have dealt with the association between HTLV (mostly HTLV-I) and chronic neurodegenerative disorders. Data from early studies conducted in North Brazil have postulated the relationship between HTLV-I infection and the development of Guillain-Barré syndrome in a 12 year-old boy ${ }^{25}$. The nationwide occurrence of HTLV-I infection in patients with HAM/TSP has been documented by several studies showing that both sexual promiscuity and blood transfusion appear to be the most important risk factors for transmission, with prevalence rates being higher among female subjects ${ }^{1,2,3,7,8,9,31}$. A pilot study conducted in Belém, Northern Brazil yielded a $9 \%$ prevalence rate of HTLV-I/II infection in a cohort of 144 patients presenting with clinical symptoms of myelopathy ${ }^{18}$. Also in Belém, Pará, Brazil, HTLV-I-associated myelopathy has been reported recently in three patients ${ }^{12}$. In addition to studies carried out in Amazonian urban communities, a possible case of HAM/TSP has been diagnosed in a remote Indian village where endemic transmission of HTLV-II is known to occur ${ }^{5,6}$.

Herein we present data from a survey of the prevalence of HTLV-I and HTLV-II infections among patients suffering from neurological diseases of unknown etiology.

\section{MATERIAL AND METHODS}

Patients: Our study cohort comprised 190 outpatients of both sexes (male subjects, 77) living in Belém, Northern Brazil - with ages ranging 


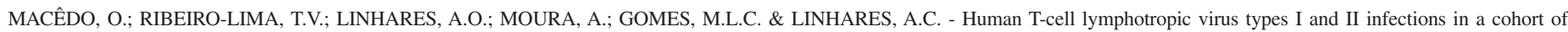
patients with neurological disorders in Belém, Pará, Brazil. Rev. Inst. Med. trop. S. Paulo, 46(1):13-17, 2004.

from 2 to 79 years - who were referred by local neurologists to the Virology Section of Instituto Evandro Chagas, over a period of six years (1996 to 2001). Overall, referred patients presented with one or more symptoms and signs gathered in the "HTLV-I-associated neurological complex", as described by MARSH ${ }^{21}$, where HAM/TSP appears as the most common clinical condition. A serological screening for HTLV infection was invariably requested for these subjects by the referring neurologists.

Samples and serological assays: Between 5 and $10 \mathrm{ml}$ of blood was obtained from each of the 190 patients using tubes without anticoagulant; sera was further separated from each sample and kept frozen at $-20^{\circ} \mathrm{C}$ until processing. In addition, cerebrospinal fluid samples (CSFs) (3 - $5 \mathrm{ml}$ each) were available from 21 subjects. Sera (and CSFs, when available) were initially screened for the presence of HTLV antibodies using a three-stage enzyme-linked immunosorbent assay (ELISA) that utilizes microwells coated with recombinant HTLV-I and HTLV-II antigens (Ortho ${ }^{\circledR}$, Raritan, NJ, USA). All specimens reacting positive in the initial screening were, thereafter, retested in duplicate by ELISA. Repeatedly reactive samples were further confirmed using a newly developed Western-blot assay (WB) ${ }^{34}$ that includes either recombinant proteins or synthetic peptides highly purified and fixed onto a nylon membrane (INNO-LIATM HTLV I/II, Immunogenetics N.V., Ghent, Belgium). As based on test principle described by manufacturers, bands corresponding to two core proteins encoded by gag gene (p19 I/II and p24 I/II) and env gene glycoprotrein products gp46 I/II (external envelope) and gp21 I/II (small transmembrane) are applied as non-typespecific antigens, to ensure that antibodies against HTLV I/II are present. Recombinant proteins/synthetic peptides applied to define typespecificities are gag p19-I and env gp46-I (HTLV-I) and env gp46-II (HTLV-II). This system allows for classification of positive samples as HTLV-I, HTLV-II, mixed HTLV-I/II or untypeable.
In an attempt to rule out aetiologies other than HTLV-I/II infection, serum samples from 11 of the 15 HTLV I/II-seropositive patients were tested for hepatitis $\mathrm{C}$ virus ( $\mathrm{HCV}$ ) antibodies by using a third-generation ELISA which includes antigens from the NS5 region (Ortho-Clinical Diagnostics, Inc., Raritan, NJ, USA). In addition to this, available medical documentation provided information on hematological values and serum glucose levels.

Statistical analysis: This was done with EPI-INFO software, version 6.0 (Atlanta, GA, USA). Comparison of rates between groups were made with the Mantel-Haenszel chi-square test of association or, if assumptions required for the chi-square test were not met, with Fisher's exact test. Significance was defined as $p<0.05$.

\section{RESULTS}

The general characteristics, clinical symptoms and laboratory findings for 15 HTLV I/II-seropositive patients are presented in Table 1, covering the period between May 1996 and December 2001. While serum samples were available for all 15 subjects, a CSF sample could be obtained from patient no. "1" only, also reacting HTLV-I-positive. Ages at presentation ranged from 21 years to 79 years, with female patients accounting for $80 \%$ of HTLV-reactive subjects. Taken together, walking difficulty $(\mathrm{n}=5$ subjects), spasticity $(\mathrm{n}=4)$ and leg weakness $(\mathrm{n}=3)$ were recorded in $80 \%$ of HTLV-seropositive patients, with reported disease duration varying from one month to 12 years. While HTLV-IIpositive subjects had either leg myalgia, walking difficulty or spasticity, the only HTLV-I/II-positive patient developed paraplegia. Figure 1 displays Western blot profiles of a representative number of HTLVseropositive patients (lanes A through I), of whom (a) six (A, B, C, D, G and $\mathrm{H}$ ) were HTLV-I reactive, (b) two (E and I) had HTLV-II antibodies, and (c) one (F) yielded a pattern compatible with a dual, concurrent

Table 1

General characteristics, symptoms and laboratory findings for 15 HTLV I/II-positive patients with neurological diseases in Belém, Brazil

\begin{tabular}{|c|c|c|c|c|c|c|}
\hline $\begin{array}{l}\text { Patient } \\
\text { no. }\end{array}$ & $\begin{array}{l}\text { Age } \\
\text { (years) }\end{array}$ & Sex & Main symptoms or diagnosis & $\begin{array}{c}\text { Duration of } \\
\text { illness* }\end{array}$ & $\begin{array}{l}\text { Month, year of } \\
\text { blood sampling }\end{array}$ & HTLV- Typing \\
\hline 1 & 62 & $\mathrm{~F}$ & Leg weakness and peripheral sensory loss & 2 years & May, $1996 * *$ & I \\
\hline 2 & 21 & $\mathrm{~F}$ & Leg weakness/trembling and walking difficulty & 2 years & December, 1996 & I \\
\hline 3 & 45 & $\mathrm{~F}$ & Hypotonia, leg myalgia and walking difficulty & 1 year & April, 1997 & I \\
\hline 4 & 55 & $\mathrm{~F}$ & Spastic paraparesis & $?$ & November, 1997 & I \\
\hline 5 & 23 & $\mathrm{~F}$ & Spastic paraparesis and paresthesia & 3 years & August, 1998 & I \\
\hline $6 * * *$ & $?$ & M & Occasional abrupt vertigo & "A few months" & February, 1999 & I \\
\hline 7 & 58 & $\mathrm{~F}$ & Leg weakness and vertigo & 3 years & September, 1999 & I \\
\hline 8 & 66 & M & Leg hypotonia and spasticity of extremities & 12 years & November, 1999 & II \\
\hline 9 & 43 & $\mathrm{~F}$ & Walking difficulty and lower limbs paresthesia & 3 years & April, 2000 & I \\
\hline 10 & 61 & $\mathrm{~F}$ & Paraplegia & 12 years & April, 2000 & $\mathrm{I}+\mathrm{II}$ \\
\hline 11 & 24 & $\mathrm{~F}$ & Walking difficulty & 2 years & June, 2000 & $\mathrm{I}$ \\
\hline 12 & 46 & $\mathrm{~F}$ & Lower limbs paraparesis & 1 year & $?$ & I \\
\hline 13 & 79 & M & Walking difficulty & 1 month & $?$ & II \\
\hline 14 & 33 & $\mathrm{~F}$ & Leg myalgia & 1 month & April, 2001 & II \\
\hline 15 & 57 & $\mathrm{~F}$ & Spastic paraparesis and walking difficulty & 5 years & December, 2001 & NT \\
\hline
\end{tabular}

*, Approximate duration of symptoms, as reported by the patient; **, HTLV-I-reactive CSF obtained from this patient on June, 1996; ***, a probable HTLV-related case; and ?, Information not available 
HTLV-I and HTLV-II infection. The annual distribution of patients according to their HTLV antibody reactions is presented in Fig. 2. Overall, seropositivity rates ranged from $2.6 \%$ to $21.7 \%$ for years 2001 and 2000 , respectively. The rates of HTLV-seropositivity tended to be higher ( $p=$ 0.15) during the biennium 1999-2000 than for the three previous years combined; the percent HTLV-reactivity in 2001 was significantly lower $(p=0.009)$ than during the rest of the six-year study period. While HTLVI-reactive subjects were identified throughout the first five consecutive years (1996 to 2000), HTLV-II infections were limited to the period of 1999 to 2001.

Patients

\begin{tabular}{lllllllllll}
\hline A & B & C & D & E & F & G & H & I & +
\end{tabular}

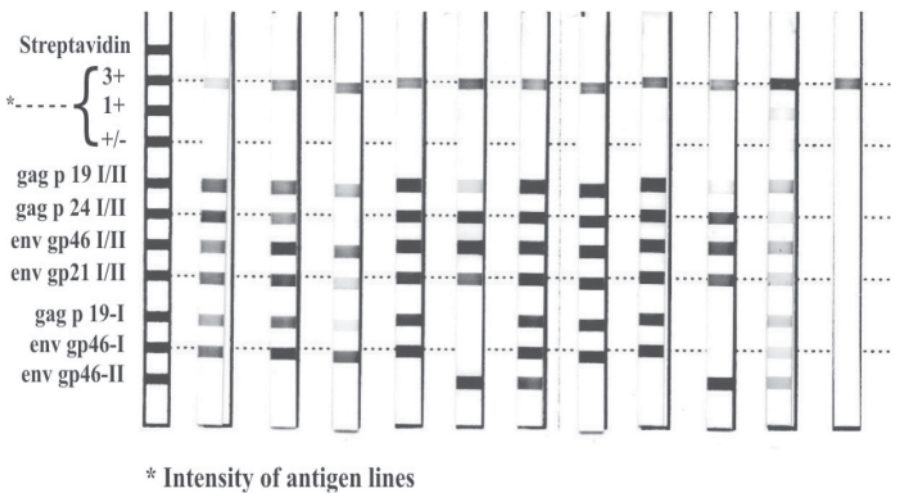

Fig. 1 - Western immunoblot for antibodies to polypeptides of humanT lymphotropic viruses types I and II. Patients A, B, C, D, G and H are HTLV-I seropositive; patients E and I are HTLV-II seropositive; and, patient F is HTLV-I/II reactive. (+) and (-) denote HTLV-reactive and HTLV-non-reactive test controls, respectively.

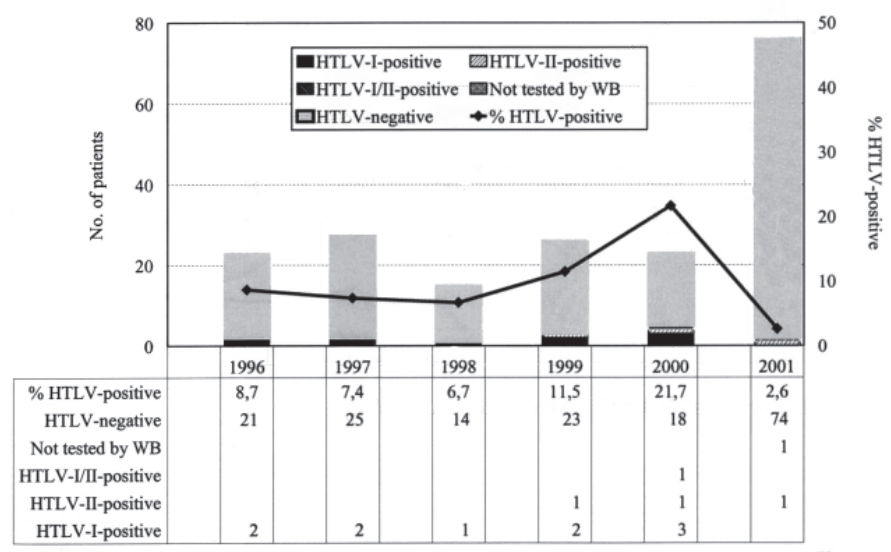

Fig. 2 - Annual distribution of tested patients according to HTLV antibody status in Belém, Brazil.

Sera from the eleven HTLV-I/II-seropositive patients who were tested for the presence of $\mathrm{HCV}$ antibodies yielded negative results and no evidence was apparent suggesting the occurrence of either diabetes mellitus or B12 and/or folate deficiencies.

\section{DISCUSSION}

Data from the present study provide evidence that HTLV-related neurological disorders in Belém, Northern Brazil appear to be of emerging public health importance ${ }^{12,18,25}$. The overall $8 \%$ seropositivity rate in our investigation is similar to that recorded in a previous, pilot local survey ${ }^{18}$ where $9 \%$ of screened patients suffering from neurological disease were found to have HTLV-I/II antibodies. The seropositivity rate in our study tended to be lower, however, if compared with those rates from other surveys conducted across Brazil, which varied from $14.7 \%$ to $57 \% \%^{1,2,8}$. A possible explanation for this difference is the fact that our study cohort comprised patients whose sera were tested for the presence of HTLV-I/ II antibodies primarily at the request of the referring local neurologists. Moreover, all referred individuals were found to present with at least one symptom or sign which would be required to assign them to the "HTLV-I-associated neurological complex", as defined by MARSH" Of note, since age could not be retrieved for "Patient no. 6" (Table I), one cannot rule out a possible relationship between vertigo and clinical conditions other than those of the "HTLV-I-associated neurological complex"21 such as dyslipidemia, degeneration of the spinal cord and vertebrobasilar insufficiency. Contrasting with this wide spectrum of neurological clinical conditions, the other studies under comparison have in general adopted a more strict criteria for inclusion of patients, namely the World Health Organization classic definition for HAM/TSP ${ }^{19,29}$. This definition includes mainly a chronic myelopathy diagnosis, as defined by the occurrence of a motor deficit with pyramidal pattern in association with autonomic involvement for at least five months.

Despite the broad age-range of patients referred for HTLV-I/II antibody screening, it is noticeable that only adults of both sexes (mean age, 48 years) were found to be reactive by both ELISA and WB. These findings are consistent with the general concept that the average age of diagnosis is 40 years, with infection being most commonly acquired during adulthood ${ }^{19}$. Our data showing that female patients accounted for $80 \%$ of HTLV-I/II seropositive results are also compatible with previous observations indicating that HAM/TSP is more common in women than men at all age groups. It should be pointed out in this regard that previous studies have suggested that such a gender difference usually becomes more evident after the age of 30 years, probably reflecting a more efficient transmission of HTLV-I from males to females during sexual intercourse ${ }^{11,19}$.

The trend toward higher reactivity rates during 1999-2000, as compared with previous years of observation, suggests that local neurologists became increasingly more aware as to the importance of screening patients with chronic myelopathies for HTLV-I/II antibodies. Intriguingly, however, is the fact that only $2.6 \%$ of patients were seropositive in 2001. Since the utilized laboratory methods did not change throughout the whole study period and age-groups were evenly distributed across the years (data not shown in table), it seems likely that such unexpected low seropositivity rate may have occurred by chance, owing to the general, relatively low number of study subjects. An alternative, though apparently paradoxical explanation, is that once fully aware of the laboratory facilities for diagnosis, clinicians were perhaps less strict when selecting patients for HTLV-I/II serological screening. Whatever explanation should be for this latest downward shift in seropositivity, more representative data on the epidemiology of HAM/ TSP in our region would only be achievable through the conduct of 


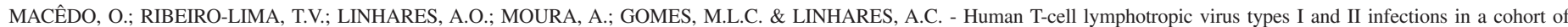
patients with neurological disorders in Belém, Pará, Brazil. Rev. Inst. Med. trop. S. Paulo, 46(1):13-17, 2004.

further studies that might gather a number of patients much larger than reported either herein or elsewhere ${ }^{12,18}$.

Although all patients referred by local neurologists have met the clinical criteria required for their inclusion in the "HTLV-I-associated neurological complex", it is noticeable that 14 of the 15 individuals who reacted HTLV-I/II-positive presented with at least one neurological/motor disorder which were compatible with the WHO definition criteria for HAM/TSP ${ }^{29}$. The fact that almost $90 \%$ of our patients reacted seronegative underscores the need for a routine differential diagnosis of HTLV-I/IIrelated neurological disorders with a variety of other clinical conditions which might be gathered in the context of either acute or chronic myelopathies ${ }^{30}$. In tropical regions like ours, parasitic diseases including toxoplasmosis, schistosomiasis and cysticercosis, for example, cannot be ruled out when seeking for the etiology of neurological disorders that might resemble some of those of HAM/TSP. Also in these settings, B12 and folate deficiencies may lead to neurological disorders that would mimic those found in HTLV-I/II-related diseases. It should be pointed out in this context, however, that sera from all 15 HTLV-reactive patients were negative when tested for hepatitis $\mathrm{C}$ antibodies by conventional enzyme immunoassays; in addition, as based on available medical documentation from these patients, there was no indication that they were suffering from diabetes mellitus or B12/folate deficiencies.

A major finding in our study was the occurrence of HTLV-II-related neurological disease in three patients, including one case in which a dual HTLV-I- and- HTLV-II infection could be diagnosed. To our knowledge, these findings seem to be the first in the Amazon region providing serological evidence that HTLV-II infection may be associated with HAM/ TSP in urban settings. Of note, BLACK et al. ${ }^{6}$ have described a possible case of TSP in a HTLV-II-seropositive, 40-year old Indian woman who lived in the Kayapo village in the Southeastern Amazon basin, Pará state, Brazil. Of importance in this context, several reports have demonstrated the endemic transmission of HTLV-II (subtypes a and c) among the Kayapo Indians of Brazil, a remote community where mother-to-child transmission (mainly via breast-feeding) appear to be especially important ${ }^{5,13,15,32}$. Additional reports have focussed on the occurrence of HTLV-II infection in selected urban populations of Belém, Brazil, namely blood donors and HIV-1 infected patients, albeit no neurological disturbances have been identified so far ${ }^{14,33}$. It is noteworthy in our study cohort the fact that HTLVII-infected patients were identified as from 1999 onwards, and a relatively short duration of their illnesses (one month) has been reported. These findings give rise to the hypothesis of possible recent introduction of HTLVII in urban settings in our region, an issue that should be taken into account when further assessing the growing public health concern as to the countrywide HTLV-I/II-related disease burden. In light of such a hypothesis, it would seem also plausible to postulate that our 61-year old paraplegic female patient with serological evidence of dual (HTLV-I and HTLV-II) infection might have been infected primarily by HTLV-I, with a subsequent, perhaps recent infection by HTLV-II.

Although serological and clinical data presented herein are strongly suggestive that a relationship exists between HTLV-I/II infection and neurological diseases in our region, it is noticeable that our study had two limitations. First, cerebrospinal fluids (CSFs) were not available from most of local patients, preventing us from having a more direct evidence of central nervous system involvement through the detection of specific antibodies in these samples. In fact, among the 15 HTLV- positive subjects, a CSF sample could be obtained from one patient only, yielding the same HTLV-typing specificity as detected in serum. Of note, all of the remainder $20 \mathrm{CSF}$ samples from HTLV-negative patients also yielded negative results. Secondly, since patients were referred primarily with the purpose of laboratory diagnosis only, data on risk factors for HTLV-I/II infection were lacking, making it difficult to trace a possible source of virus transmission among affected individuals.

A clearer understanding on the epidemiological features of HAM/ TSP in our region is needed. In order to achieve this goal, however, comprehensive further studies should be conducted including a more extensive screening of patients for HTLV-I/II antibodies in their sera and (whenever possible) CFS samples. By the way, like in other endemic regions for HTLV-I infection, additional features such as susceptibility and rapid/ low disease progression are worth of exploring further ${ }^{11}$. It is also worth in this regard to strengthen the awareness of local neurologists and clinicians as to the public health importance of seeking for a laboratory diagnosis whenever symptoms may suggest the occurrence of HAM/TSP. Finally, monitoring of HTLV-I and HTLV-II circulating strains/subtypes should be encouraged through the use of molecular biology techniques.

\section{RESUMO}

Infecção pelos vírus linfotrópicos humanos de células T tipos I e II entre pacientes com doença neurológica em Belém, Pará, Brasil

Amostras de soro e/ou líquido céfalo-raquidiano (LCR) foram obtidas de 190 pacientes com quadro de doença neurológica crônica e progressiva, com vistas à detecção de anticorpos para os vírus linfotrópicos humanos de células T dos tipos I (HTLV-I) e II (HTLV-II), durante um período de seis anos (1996 a 2001) em Belém, Pará, Brasil. O grupo compreendia ambos os sexos (homens, 52\%), com idades variando de 2 a 79 anos (média, 35,9 anos). Tomando-se os resultados como um todo, 15 (7,9\%) indivíduos, incluindo $12(80 \%)$ mulheres adultas, apresentaram anticorpos para HTLVI/II a partir da triagem pelo procedimento imunoenzimático (ELISA). Soros de 14 desses pacientes também foram testados utilizando-se procedimento de Western blot (WB), alcançando-se frequiências de anticorpos para HTLVI, HTLV-II e dupla reação (HTLV-I e HTLV-II) em 10 (71,4\%), 3 (21,4\%) e $1(7,2 \%)$ indivíduos, respectivamente. As freqüências anuais de positividade para HTLV-I/II variaram de 2,6\% (2001) a 21,7\% (2000), em escala crescente no período de 1998 a 2000. Em conjunto, dificuldade na deambulação $(n=5$ pacientes), espasticidade $(n=4)$ e hipotonia crural compreenderam $80 \%$ das manifestações clínicas registradas entre os 15 pacientes cujas amostras de soro continham anticorpos para HTLV-I/II, com base em ELISA. Tais resultados oferecem indicadores quanto a uma possível associação do HTLV-I e do HTLV-II à gênese das mielopatias crônicas em Belém, norte do Brasil.

\section{ACKNOWLEDGMENTS}

Thanks are due to local neurologists for their attention and interest in referring patients to be screened for HTLV-I/II antibodies at Instituto Evandro Chagas.

\section{REFERENCES}

1. ANDRADE-FILHO, A.S.; BRITES, C.; DOS SANTOS, S.R.S. et al. - HTLV-I/II as a common etiology of myelopathies in Bahia, Brazil. Braz. J. med. biol. Res., 29: 757-761, 1996. 


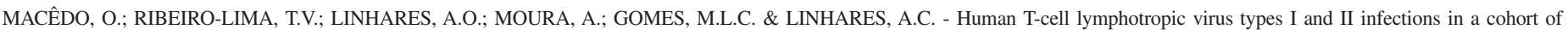
patients with neurological disorders in Belém, Pará, Brazil. Rev. Inst. Med. trop. S. Paulo, 46(1):13-17, 2004.

2. ARAUJO, A. de Q. \& ANDRADA-SERPA, M.J. - Tropical spastic paraparesis/HTLV-Iassociated myelopathy in Brazil. J. AIDS hum. Retrovirol., 13 (suppl. 1): S33-S37, 1996.

3. ARAUJO, A.Q.; ANDRADE-FILHO, A.S.; CASTRO-COSTA, C.M.; MENNABARRETO, M. \& ALMEIDA, S.M. - HTLV-I-associated myelopathy/tropical spastic paraparesis in Brazil: a nationwide survey. HAM/TSP Brazilian Study Group. J. AIDS hum. Retrovirol., 19: 536-541, 1998.

4. BARTHOLOMEW, C.; CLEGHORN, F.; JACK, N.; EDWARDS, J. \& BLATTNER, W. - Human T-cell lymphotropic virus type-I-associated facial nerve palsy in Trinidad and Tobago. Ann. Neurol., 41: 806-809, 1997.

5. BLACK, F.L.; BIGGAR, R.J.; LAL, R.B.; GABBAI, A.A. \& VIEIRA FILHO, J.P.B. Twenty-five years of HTLV type II follow-up with a possible case of tropical spastic paraparesis in the Kayapo, a Brazilian Indian tribe. AIDS Res. Hum. Retroviruses, 12: $1623-1627,1996$

6. BLACK, F.L.; BIGGAR, R.J.; NEEL, J.V.; MALONEY, E.M. \& WATERS, D.J. - Endemic transmission of HTLV type II among Kayapo Indians of Brazil. AIDS Res. Hum. Retroviruses, 10: 1165-1171, 1994

7. CASTRO, L.H.M.; CHAVES, C.J.; CALLEGARO, D.; NOBREGA, J.P.S \& SCAFF, M. - HTLV-I associated myelopathy in Brazil: a preliminary report. Arq. Neuropsiquiat. (S. Paulo), 47: 501-502, 1989.

8. DOMINGUES, R.B.; MUNIZ, M.R.; JORGE, M.L.G. et al. - Human T cell lymphotropic virus type-1 associated myelopathy/tropical spastic paraparesis in São Paulo, Brazil: association with blood transfusion. Amer. J. trop. Med. Hyg., 57: 56-59, 1997.

9. FIGUEIRÔA, F.L.S.; ANDRADE-FILHO, A.S.; CARVALHO, E.S.; BRITES, C. \& BADARÓ, R. - HTLV-I associated myelopathy: clinical and epidemiological profile. Braz. J. infect. Dis., 4: 126-130, 2000

10. GESSAIN, A.; BARIN, F.; VERNANT, J.C. et al. - Antibodies to human T-lymphotropic virus type I in patients with tropical spastic paraparesis. Lancet, 2: 407-410, 1985.

11. GREEN, P.L. \& CHEN, I.S.Y. - Human T-cell leukemia virus types 1 and 2. In: KNIPE, D.M.; HOWLEY, P.; GRIFFIN, D.E. et al., ed. Fields Virology. Philadelphia, Lippincott Williams \& Wilkins, 2001. p. 1941-1969.

12. ISHAK, R.; CAVALCANTE, F.; VALLINOTO, A.C.R.; AZEVEDO, V.N. \& ISHAK M.O.G. - HTLV-I associated myelopathy in the northern region of Brazil (Belém, Pará): serological and clinical features of three cases. Rev. Soc. bras. Med. trop, 35 : 243-246, 2002.

13. ISHAK, R.; HARRINGTON Jr., W.J.; AZEVEDO, V.N. et al. - Identification of human $\mathrm{T}$ cell lymphotropic virus type IIa infection in the Kayapo, an indigenous population of Brazil. AIDS Res. hum. Retroviruses, 11: 813-821, 1995.

14. ISHAK, R.; ISHAK, M.O.G.; AZEVEDO, V.N. et al. - Identification of HTLV-IIa in blood donors in an urban area of the Amazon region of Brazil (Belém, PA). Rev. Soc. bras. Med. trop. , 31: 193-197, 1998.

15. ISHAK, R.; VALLINOTO, A.C.R.; AZEVEDO, V.N. et al. - Molecular evidence of mother-to-child transmission of HTLV-IIc in the Kararao village (Kayapo) in the Amazon region of Brazil. Rev. Soc. bras. Med. trop., 34: 519-525, 2001.

16. KAPLAN, J.E.; LITCHFIELD, B.; ROUAULT, C. et al. - HTLV-I associated myelopathy associated with blood transfusion in the United States: epidemiologic and molecular evidence linking donor and recipient. Neurology, 41: 192-197, 1991.

17. La GRENADE, L.; HANCHAD, B.; FLETCHER, V.; CRANSTON, B. \& BLATTNER, W. - Infective dermatitis of Jamaican children: a marker for HTLV-I infection. Lancet, 336: $1345-1347,1990$.
18. MACÊDO, O.; RIBEIRO LIMA, T.V. \& LINHARES, A.C. - Human T cell lymphotropic virus type I infection and neurological disease in Belém, Brazil. In: SIMPÓSIO INTERNACIONAL SOBRE HTLV NO BRASIL, 6., Salvador, 2000. Resumos.

19. MANNS, A.; HISADA, M. \& La GRENADE, L. - Human T-lymphotropic virus type infection. Lancet, 353: 1951-1958, 1999.

20. MARIETTE, X.; CHEROT, P.; CAZALS, D. et al. - Antibodies to HTLV-I in Sjögren's syndrome. Lancet, 345: 71, 1995

21. MARSH, B.J. - Infectious complications of human T-cell leukemia/lymphoma virus type I infection. Clin. infect. Dis., 23: 138-145, 1996.

22. MOCHIZUKI, M.; ONO, A.; IKEDA, E. et al. - HTLV-I uveitis. J. AIDS hum. Retrovirol., 13 (suppl. 1): S50-S56, 1996.

23. MORGAN, O.S.; RODGERS-JOHNSON, P.; MORA, C. \& CHAR, G. - HTLV-I and polymyositis in Jamaica. Lancet, 2: 1184-1187, 1989.

24. MOTOKAWA, S.; HASUNUMA, T.; TAJIMA, K. et al. - High prevalence of arthropathy in HTLV-I carriers on a Japanese island. Ann. rheum. Dis., 55: 193-195, 1996.

25. NAKAUCHI, C.M.; LINHARES, A.C.; GOMES, M.L.C. et al. - Antibody to human Tlymphotropic virus in a patient with Guillain-Barré syndrome (case report). Rev. Inst. Med. trop. S. Paulo, 33: 329-331, 1991.

26. OSAME, M.; JANSSEN, R.; KUBOTA, H. et al. - Nationwide survey of HTLV-I associated myelopathy in Japan: association with blood transfusion. Ann. Neurol. 28: $50-56,1990$

27. OSAME, M.; USUKU, K.; IZUMO, S. et al. - HTLV-I associated myelopathy, a new clinical entity. Lancet, 1: 1031-1032, 1986.

28. POIESZ, B.J.; RUSCETTI, F.W.; GAZDAR, A.F. et al. - Detection and isolation of type $C$ retrovirus particles from fresh and cultured lymphocytes of a patient with cutaneous T-cell lymphoma. Proc. nat. Acad. Sci. (Wash.), 77: 7415-7419, 1980.

29. REPORT OF THE SCIENTIFIC GROUP CONVENED BY THE WHO REGIONAL OFFICE FOR THE WESTERN PACIFIC, Kagoshima, Japan, 10-15 December 1988 - Human T lymphotropic virus type I, HTLV-I. Wkly. Epidem. Rep., 49: 382-383, 1989.

30. RIBAS, J.G.R. \& DE MELO, G.C.N. - Mielopatia associada ao vírus linfotrópico humano de células T do tipo 1 (HTLV-1). Rev. Soc. bras. Med. trop., 35: 377-384, 2002.

31. SEGURADO, A.A.C.; MALAQUE, C.M.S.; SUMITA, L.M.; PANNUTI, C.S. \& LAL, R.B. - Laboratory characterization of human T cell lymphotropic virus types 1 (HTLV1) and 2 (HTLV-2) infections in blood donors from São Paulo, Brazil. Amer. J. trop. Med. Hyg., 57: 142-148, 1997.

32. SWITZER, W.M.; BLACK, F.L.; PIENIAZEK, D. et al. - Endemicity and phylogeny of the human T cell lymphotropic virus type II subtype A from the Kayapo Indians of Brazil: evidence for limited regional dissemination. AIDS Res. hum. Retroviruses, 12: 635-640, 1996.

33. VALLINOTO, A.C.R.; AZEVEDO, V.N.; SANTOS, D.E.M. et al. - Serological evidence of HTLV-I and HTLV-II coinfections in HIV-1 positive patients in Belém, state of Pará, Brazil. Mem. Inst. Oswaldo Cruz, 93: 407-409, 1998.

34. ZREIN, M.; LOUWAGIE, J.; BOEYKENS, H. et al. - Assessment of a new immunoassay for serological confirmation and discrimination of human T-cell lymphotropic virus infections. Clin. diagn. Lab. Immunol., 5: 45-49, 1998.

Received: 10 July 2003

Accepted: 19 December 2003 